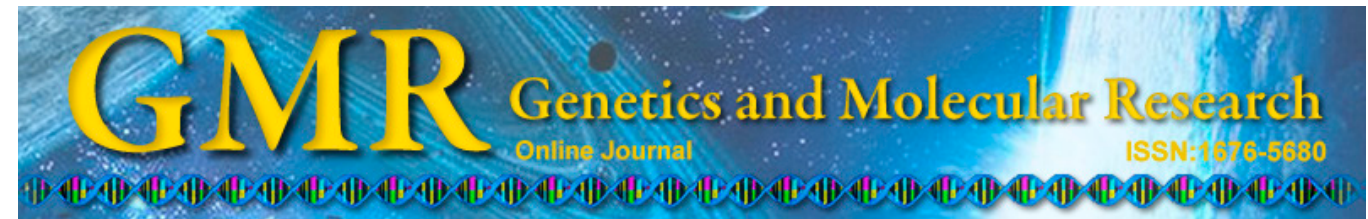

\title{
Mechanisms of cytotoxicity induced by the anesthetic isoflurane: the role of inositol 1,4,5-trisphosphate receptors
}

\author{
W.-H. Zhai ${ }^{1}$, J. Zhao' ${ }^{2}$, S.-P. Huo ${ }^{3}$, X.-G. Chen ${ }^{3}$, Y.-D. Li ${ }^{1}$, Z.-L. Zhang ${ }^{1}$, \\ L.-L. Yu ${ }^{4}$, S. Song ${ }^{5}$ and Q.-J. Wang ${ }^{3}$ \\ ${ }^{1}$ Department of Anesthesiology, Affiliated Hospital of Jining Medical University, \\ Jining, China \\ ${ }^{2}$ Department of Cell Biology, School of Basic Medical Sciences, \\ Hebei Medical University, Shijiazhuang, Hebei, China \\ ${ }^{3}$ Department of Anesthesiology, Third Hospital of Hebei Medical University, \\ Shijiazhuang, Hebei, China \\ ${ }^{4}$ Department of Anesthesiology, Cangzhou Central Hospital, Cangzhou, China \\ ${ }^{5}$ Department of Anesthesiology, Yuhuanding Hospital, Yantai, China \\ Corresponding author: Q.-J. Wang \\ E-mail: qiujunwang@126.com
}

Genet. Mol. Res. 14 (2): 6929-6942 (2015)

Received October 11, 2014

Accepted December 16, 2014

Published June 26, 2015

DOI http://dx.doi.org/10.4238/2015.June.26.1

\begin{abstract}
Isoflurane can induce widespread cytotoxicity. We hypothesized that isoflurane induces apoptosis partly by causing excessive calcium release from the endoplasmic reticulum (ER) via direct activation of inositol 1,4,5-trisphosphate receptors (IP ${ }_{3}$ ). Rat pheochromocytoma cells cultured for seven days with nerve growth factor were divided into four groups: control group $(\mathrm{C}), \mathrm{IP}_{3} \mathrm{R}$ antagonist group $(\mathrm{X})$, isoflurane group (I) and isoflurane $+\mathrm{IP}_{3} \mathrm{R}$ antagonist group $(\mathrm{I}+\mathrm{X})$. Groups I and $\mathrm{I}+\mathrm{X}$ were treated with $1 \mathrm{MAC}$ isoflurane for $12 \mathrm{~h}$. Groups $\mathrm{X}$ and $\mathrm{I}+\mathrm{X}$ were pretreated with $\mathrm{IP}_{3} \mathrm{R}$ antagonist. Annexin V/PI apoptosis and TUNEL assays were performed to evaluate cell apoptosis. TEM was used to observe changes in cell ultrastructure. Changes in
\end{abstract}


calcium concentration $\left(\left[\mathrm{Ca}^{2+}\right]_{\mathrm{i}}\right)$ in the cytoplasm were measured by flow cytometry. RT-PCR was performed to evaluate $\mathrm{IP}_{3} \mathrm{R}$ mRNA expression. TEM showed that isoflurane treatment altered cell ultrastructure. Compared to group $\mathrm{C}$, cell apoptosis rate and $\left[\mathrm{Ca}^{2+}\right]_{\mathrm{i}}$ increased in groups $\mathrm{I}$ and $\mathrm{I}+\mathrm{X}(\mathrm{P}<0.05)$. Compared to group $\mathrm{C}, \mathrm{IP}_{3} \mathrm{R}$ mRNA expression was lower in group $\mathrm{X}$ and higher in group $\mathrm{I}(\mathrm{P}<0.05)$. Compared to group $\mathrm{X}$, cell apoptosis rate, $\left[\mathrm{Ca}^{2+}\right]_{\mathrm{i}}$ and $\mathrm{IP}_{3} \mathrm{R}$ mRNA expression increased in groups I and $\mathrm{I}+\mathrm{X}(\mathrm{P}<0.05)$. Compared to group I, cell apoptosis rate, $\left[\mathrm{Ca}^{2+}\right]_{\mathrm{i}}$ and $\mathrm{IP}_{3} \mathrm{R}$ mRNA expression decreased in group $\mathrm{I}+\mathrm{X}(\mathrm{P}<0.05)$. These results suggest that exposure to $1 \mathrm{MAC}$ isoflurane for $12 \mathrm{~h}$ causes excessive calcium release partly by direct activation of $\mathrm{IP}_{3} \mathrm{R}$ on the ER membrane and triggers cell apoptosis.

Key words: Isoflurane; Apoptosis; Endoplasmic reticulum; Calcium; Inositol 1,4, 5-trisphosphate receptors

\section{INTRODUCTION}

Annually, more than 200 million people undergo surgery worldwide, most of which is carried out under general anesthesia using inhalational anesthetics such as sevoflurane, isoflurane and desflurane. Although these anesthetics are generally considered to be safe in clinical anesthesia, several studies have shown that these agents can cause cell damage, neurodegeneration or postoperative cognitive decline (Yang et al., 2008; Wang et al., 2009; Wei and Xie, 2009; Zhu et al., 2010; Bittner et al., 2011; Campbell et al., 2011; Zou et al. 2011). The common inhalational anesthetic isoflurane induces cytotoxicity in both a concentration- and time-dependent manner in different types of cultured cells.

Isoflurane exposure has been shown to cause cytotoxicity in various tissues and cells, including hippocampal slices (Wise-Faberowski et al., 2005), lymphocytes (Wei et al., 2008; Yang et al., 2008), neuroglioma cells (Xie et al., 2006a, 2007), hepatocytes (Mallédant et al., 1990), gingival fibroblasts (Chang and Chou, 2001), the PC12 neurosecretory cell line (Wei et al., 2005), and striatal neurons (Wei et al., 2008). Interestingly, these cells have different intrinsic sensitivity to anesthetic-induced toxicity (Kvolik et al., 2005; Kim et al., 2006; Xie et al., 2006a, 2006b, 2007).

The mechanisms of isoflurane-induced cell apoptosis are still unclear. Our previous study demonstrated that exposure to isoflurane at 1 minimal alveolar concentration (MAC) for $12 \mathrm{~h}$ or at $2 \mathrm{MAC}$ for $8 \mathrm{~h}$ decreased cell viability, and these effects might have been associated with the disruption of intracellular calcium homeostasis (Wang et al., 2010). Intracellular calcium homeostasis is primarily regulated by three protein receptors on the endoplasmic reticulum (ER): inositol 1,4,5-trisphosphate receptors $\left(\mathrm{IP}_{3} \mathrm{R}\right)$, ryanodine receptor $(\mathrm{RyR})$ and $\mathrm{Ca}^{2+}$-ATPases (Luciani et al., 2009). IP $\mathrm{R}$ and calcium release from the ER are key factors of intracellular signal transduction. Furthermore, $\mathrm{IP}_{3} \mathrm{R}$ hyperactivity may induce cell apoptosis. Zhao et al. (2010) suggested that the hyperactivation of $\mathrm{IP}_{3} \mathrm{R}$ may play an important role in intracellular calcium imbalance, but it is still unclear whether this is a direct effect of $\mathrm{IP}_{3} \mathrm{R}$. Therefore, we investigated whether isoflurane induced cell apoptosis via direct overactivation of $\mathrm{IP}_{3} \mathrm{R}$. 


\section{MATERIAL AND METHODS}

\section{Trial registration}

The trial registration occurred at Third Hospital of Hebei Medical University.

\section{Design}

The study design was randomied, placebo-controlled, double blinded.

\section{Ethics}

Ethical approval for this study was provided by the Ethical Committee of Third Hospital of Hebei Medical University, Shijiazhuang, China (Chairperson Prof. Yingze Zhang) on January 8, 2011.

\section{Cell culture}

Isoflurane exposure has been shown to cause cell damage in various neuronal and non-neuronal tissues and cells. We selected the PC12 neurosecretory cell line, because these cells possess neuroendocrine properties, have a high multiplication rate, and most importantly, are vulnerable to anesthetic-induced neurotoxicity. PC12 cells were induced to differentiate by nerve growth factor (NGF) and cultured in DMEM with 10\% fetal bovine serum, 5\% horse serum, $4 \mathrm{mM} \mathrm{L}$-glutamine, and antibiotics in a 95\% air-5\% $\mathrm{CO}_{2}$ humidified incubator at $37.5^{\circ} \mathrm{C}$. Medium was changed every two days, and cells were passage at $\sim 70$ to $80 \%$ confluence. Cells were randomly divided into four groups: control group (C), IP ${ }_{3} \mathrm{R}$ antagonist group (X), isoflurane group (I), and isoflurane and $\mathrm{IP}_{3} \mathrm{R}$ antagonist group (I+X). Before exposure to isoflurane, medium was changed to non-serum containing DMEM.

\section{Anesthetic exposure}

Groups I and I+X were exposed to $1 \mathrm{MAC}(1.2 \%)$ isoflurane for $12 \mathrm{~h}$ in a gastight chamber inside the incubator, with humidified 5\% $\mathrm{CO}_{2}-21 \% \mathrm{O}_{2}$-balanced $\mathrm{N}_{2}$ passing through a calibrated agent-specific vaporizer. The gas phase was imported at the desired concentrations throughout the experiments using an infrared Ohmeda 5330 agent monitor. Through highperformance liquid chromatography measurements, others have verified that the anesthetic concentration in the media is equivalent to the MAC in the gas phase inside the gas chamber (Nour et al., 2002). Thirty minutes before isoflurane exposure, $100 \mathrm{nM}$ xestospongin $\mathrm{C}$ was added to the medium of groups X and I+X (Oka et al., 2002). Groups C and X were placed directly in the incubator without any additional treatment.

\section{Analysis of annexin $\mathrm{V}$ and propidium iodide (PI) staining}

One of the early indications of cell damage is that the phospholipid phosphatidylserine translocates from the inner to the outer leaflet of the plasma membrane. Annexin V, a phospholipid-binding protein with a high affinity for phosphatidylserine, can bind to phos- 
phatidylserine once it is exposed to an environmental stress. PI can bind to nucleic acids after penetrating a breached plasma membrane, which occurs in the later stages of cell damage. Immediately after treating the four groups as indicated above, we analyzed the cells with an Annexin V/PI apoptosis kit (Multisciences, catalog \#: AP 101-30). We collected 1-5 x 105 cells by centrifugation, re-suspended cells in $500 \mu \mathrm{L} 1 \mathrm{X}$ binding buffer, and added $5 \mu \mathrm{L}$ annexin V-FITC and $10 \mu \mathrm{L}$ PI. The cells were incubated at room temperature for $5 \mathrm{~min}$ in the dark, and we then determined the number of annexin V- and/or PI-positive cells by flow cytometry (FCM).

\section{Detection of apoptosis by the TdT-mediated dUTP nick-end labeling (TUNEL) assay}

Apoptosis is characterized by certain morphological features, including membrane blebbing, nuclear and cytoplasmic shrinkage and chromatin condensation. The TUNEL assay is a simple, accurate and rapid method for the detection of apoptotic cells in situ at the single-cell level by measuring nuclear DNA fragmentation. Biotinylated nucleotide is incorporated at the 3'-OH DNA ends using the recombinant terminal deoxynucleotidyl transferase (rTdT) enzyme. Using this procedure, apoptotic nuclei are stained dark brown. Cells were centrifuged, washed in PBS, resuspended and plated on poly-L-lysine-coated slides on a six-well plate. One day later, cells adhering to the slides were exposed to isoflurane at 1 MAC for $12 \mathrm{~h}$. Immediately after isoflurane exposure, slides were immersed in $10 \%$ buffered formalin for $25 \mathrm{~min}$, washed in PBS, and immersed in $0.2 \%$ Triton 100X in PBS for 5 min to permeabilize the cells, and $100 \mu \mathrm{L}$ equilibration buffer were then added. Slides were then labeled with $100 \mu \mathrm{L}$ TdT reaction mix for $60 \mathrm{~min}$ at $37^{\circ} \mathrm{C}$, immersed in $0.3 \%$ hydrogen peroxide for 3-5 min, stained with DAB, and counterstained with methyl green. Stained cells were observed with a light microscope and the apoptosis index (AI) was calculated. $\mathrm{AI}=$ (number of apoptotic cells/total observed cells number) $\mathrm{x} 100 \%$. Nuclei with obvious tan particles were considered a positive indicator of apoptosis. At later stages of apoptosis, DNA fragments can pass through the nuclear membrane and spread to the cytoplasm, causing the cytoplasm to stain tan as well. The positive cells were counted in three random highpower fields (400X) on each slide.

\section{Cell ultrastructure observed with transmission electron microscopy (TEM)}

After experimental treatments, cells from groups $\mathrm{C}$ and I were collected and fixed in $2.5 \%$ glutaraldehyde. After dehydration, soaking, and embedding, samples were sliced and stained to prepare TEM specimens to observe alterations in the cell ultrastructure.

\section{FCM determination of $\left[\mathrm{Ca}^{2+}\right]_{\mathrm{i}}$}

$\left[\mathrm{Ca}^{2+}\right]_{\mathrm{i}}$ was measured by FCM. Cells were washed and incubated for $24 \mathrm{~h}$ at $37^{\circ} \mathrm{C}$ in $\mathrm{NaCl}$ Ringer's solution containing $1 \mathrm{mM} \mathrm{CaCl} \mathrm{C}_{2}$ or in Na-gluconate solution (in mM: $125 \mathrm{Na}$ D-gluconate, $5 \mathrm{~K}$-D-gluconate, $1 \mathrm{MgSO}_{4}, 32 \mathrm{HEPES} / \mathrm{NaOH}, \mathrm{pH}$ 7.4, 5 glucose) containing $1 \mathrm{mM}$ Ca-D-gluconate ${ }_{2}$. Cells were then loaded with Fluo3/AM in $\mathrm{CaCl}_{2}(1 \mathrm{mM})$-containing $\mathrm{NaCl}$ or Na-gluconate Ringer's solution with $2 \mu \mathrm{M}$ Fluo3/AM. Cells were incubated at $37^{\circ} \mathrm{C}$ for 15 min with shaking, washed twice and re-suspended in $\mathrm{CaCl}_{2}(2 \mathrm{mM})$-containing $\mathrm{NaCl}$ Ringer's solution. $\mathrm{Ca}^{2+}$-dependent Fluo3/AM fluorescence intensity (FI) was then measured in fluorescence channel FL-1, which represents $\left[\mathrm{Ca}^{2+}\right]_{\mathrm{i}}$. 


\section{Reverse transcription-polymerase chain reaction (RT-PCR)}

RT-PCR analysis was performed to determine the expression level of IP ${ }_{3} \mathrm{R}$ in the ER. During the reaction, cDNA of the gene of interest and glyceraldehyde-3-phosphate dehydrogenase (GAPDH) were co-amplified in a single PCR reaction. We used the SV total RNA isolation system (Promega Z3100) to extract total RNA from PC12 cells. Concentration and purity of RNA were determined by the absorbance values at $260 \mathrm{~nm}$. A reverse transcription system (Promega A3500) was used to reverse transcribe RNA to cDNA. Reverse transcription reactions were performed in a $20-\mu \mathrm{L}$ reaction volume. Conditions of the RT reaction were as follows: $42^{\circ} \mathrm{C}$ for $15 \mathrm{~min}, 95^{\circ} \mathrm{C}$ for $5 \mathrm{~min}$, and $4^{\circ} \mathrm{C}$ for $5 \mathrm{~min}$. GoTaq Green Master Mix (Promega M7122) was used. The primers for $\mathrm{IP}_{3} \mathrm{R}$ and GAPDH were as follows: $\mathrm{IP}_{3} \mathrm{R}$ forward: 5'-CAGGTTCAACTGCTGGTTACTAGCC-3', IP ${ }_{3} \mathrm{R}$ reverse: 5'-GGTCACGCTCGGACCGC ATC-3', and the product segment was $796 \mathrm{bp}$; GAPDH forward: 5'-CCCATCACCATCTTCC AGGAGCG-3', GAPDH reverse: 5'-ATGCAGGGATGATGTTCTGGGCTGCC-3', and the product segment was $412 \mathrm{bp}$. PCR was run with the following conditions: $94^{\circ} \mathrm{C}$ for $2 \mathrm{~min}, 35$ cycles of $94^{\circ} \mathrm{C}$ for $30 \mathrm{~s}, 55^{\circ} \mathrm{C}$ for $30 \mathrm{~s}$ and $72^{\circ} \mathrm{C}$ for $1 \mathrm{~min}$, and $72^{\circ} \mathrm{C}$ for $5 \mathrm{~min}$. PCR products $(5 \mu \mathrm{L})$ were loaded on $1 \%$ agarose gels, stained with ethidium bromide (EB), and separated by electrophoresis at $100 \mathrm{~V}$ for $30 \mathrm{~min}$ until the EB ran through about two-thirds of the gel. The gel was quantified by densitometry. The expression level of $\mathrm{IP}_{3} \mathrm{R}$ was quantified relative to that of GAPDH PCR products. GAPDH expression did not differ between groups.

\section{Statistical analysis}

Data were analyzed by the SPSS 13.0 statistics software. All data met the normality and homogeneity of variance and are reported as means \pm SD. Data were then analyzed by one-way ANOVA followed by a Newman-Keuls multiple comparison test. $\mathrm{P}<0.05$ was considered to be statistically significant.

\section{RESULTS}

\section{Isoflurane induced apoptosis in PC12 cells}

Using the annexin V/PI and TUNEL assays, we found that the apoptosis rate increased in groups I and $\mathrm{I}+\mathrm{X}(\mathrm{P}<0.05)$, but there was no significant difference in group $\mathrm{X}(\mathrm{P}>0.05)$, as compared to group $\mathrm{C}$. Compared to group $\mathrm{X}$, the apoptosis rate increased in groups I and $\mathrm{I}+\mathrm{X}(\mathrm{P}<0.05)$. In addition, compared to group $\mathrm{I}$, the apoptosis rate decreased in group $\mathrm{I}+\mathrm{X}(\mathrm{P}$ $<0.05$ ) (Table 1, Figure 1-4). These results suggest that $100 \mathrm{nM}$ xestospongin $\mathrm{C}$ alone had no effect on cell apoptosis and that exposure to $1 \mathrm{MAC}$ isoflurane for $12 \mathrm{~h}$ induced cell apoptosis, which might have been associated with $\mathrm{IP}_{3} \mathrm{R}$ activity. Thus, inhibition of $\mathrm{IP}_{3} \mathrm{R}$ activity partly reduced isoflurane-induced cell apoptosis.

\section{Effects of isoflurane on ultrastructure of PC12 cells}

The TEM results (Figure 5) showed that cells in group $\mathrm{C}$ had a smooth nuclear membrane and slight expansion and degranulation of the ER. In contrast, cells in group I had significant morphological alterations. Specifically, the nuclear shape changed, the nuclear chro- 
matin boundary shifted, the perinuclear gap was modestly broadened, the density of ribosomes increased, the structure of organelles was incomplete, the mitochondria and ER showed a moderate to high degree of swelling, mitochondrial cristae were disordered, membrane structure was damaged, and microtubule microfilament contents increased.

Table 1. Comparisons of the apoptosis rate (AR) by annexin V/PI assay, the apoptosis index (AI) by TUNEL assay, the calcium concentration in the cytoplasm $\left(\left[\mathrm{Ca}^{2+}\right]_{i}\right)$, and the $\mathrm{IP}_{3} \mathrm{R}$ mRNA expression in the four groups.

\begin{tabular}{lcccc}
\hline Group & $\mathrm{C}$ & $\mathrm{X}$ & $\mathrm{I}$ & $\mathrm{I}+\mathrm{X}$ \\
\hline $\mathrm{AR}(\%, \mathrm{~N}=6)$ & $2.5 \pm 0.7$ & $2.4 \pm 0.8$ & $7.6 \pm 0.7^{\mathrm{ab}}$ & $5.3 \pm 0.3^{\mathrm{abc}}$ \\
$\mathrm{AI}(\%, \mathrm{~N}=18)$ & $4.9 \pm 0.4$ & $4.7 \pm 0.4$ & $12.1 \pm 1.0^{\mathrm{ab}}$ & $7.4 \pm 0.3^{\mathrm{abc}}$ \\
{$\left[\mathrm{Ca}^{2}\right]_{\mathrm{i}}(\mathrm{N}=6)$} & $9.3 \pm 0.9$ & $9.4 \pm 0.9$ & $16.1 \pm 0.8^{\mathrm{ab}}$ & $13.6 \pm 0.8^{\mathrm{abc}}$ \\
$\mathrm{IP}_{3} \mathrm{R}(\mathrm{N}=6)$ & $1.002 \pm 0.008$ & $0.892 \pm 0.004^{\mathrm{a}}$ & $1.061 \pm 0.006^{\mathrm{ab}}$ & $0.994 \pm 0.006^{\mathrm{bc}}$ \\
\hline
\end{tabular}

Data are reported as means $\pm \mathrm{SD}$. Compared to group $\mathrm{C}$, ${ }^{\mathrm{P}} \mathrm{P}<0.05$; compared to group $\mathrm{X}$, ${ }^{\mathrm{b}} \mathrm{P}<0.05$; compared to group $\mathrm{I},{ }^{\mathrm{c}} \mathrm{P}<0.05$. Compared to group $\mathrm{C}$, cell apoptosis rate and $\left[\mathrm{Ca}^{2+}\right]_{\mathrm{i}}$ increased in groups $\mathrm{I}$ and $\mathrm{I}+\mathrm{X}(\mathrm{P}<0.05)$, but there was no significant difference in group $\mathrm{X}(\mathrm{P}>0.05)$. The $\mathrm{IP}_{3} \mathrm{R}$ mRNA expression was lower in group $\mathrm{X}$, the $\mathrm{IP}_{3} \mathrm{R}$ expression was higher in group I $(\mathrm{P}<0.05)$, but there was no significant difference in group $\mathrm{I}+\mathrm{X}(\mathrm{P}>0.05)$. Compared to group $\mathrm{X}$, cell apoptosis rate, $\left[\mathrm{Ca}^{2+}\right]_{\mathrm{i}}$ and $\mathrm{IP}_{3} \mathrm{R}$ mRNA expression increased in groups I and $\mathrm{I}+\mathrm{X}(\mathrm{P}<$ $0.05)$. Compared to group $I$, cell apoptosis rate, $\left[\mathrm{Ca}^{2+}\right]_{\mathrm{i}}$ and the $\mathrm{IP}_{3} \mathrm{R}$ mRNA expression decreased in group $\mathrm{I}+\mathrm{X}(\mathrm{P}$ $<0.05)$. These results suggest that exposure to 1 MAC isoflurane for $12 \mathrm{~h}$ causes excessive calcium release partly by direct activation of $\mathrm{IP}_{3} \mathrm{R}$ on ER membranes, thereby triggering cell apoptosis.
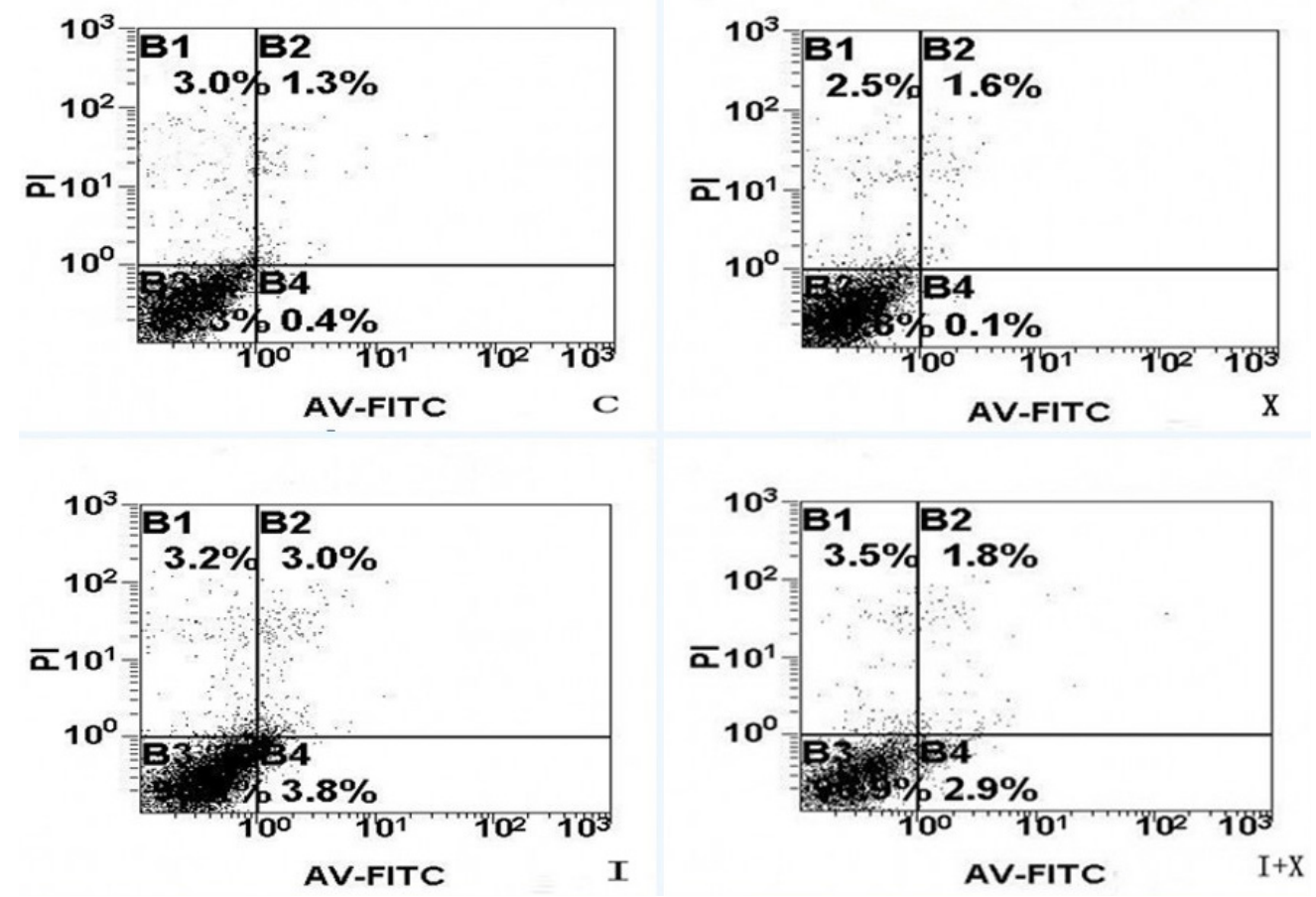

Figure 1. Apoptosis rate determined by the annexin V/PI assay. Annexin V-FITC and PI were used to detect cell apoptosis, where $\mathrm{FITC}^{-} / \mathrm{PI}^{-}$represents living cells, $\mathrm{FITC}^{+} / \mathrm{PI}^{-}$represents early apoptotic cells, $\mathrm{FITC}^{+} / \mathrm{PI}^{+}$represents middle-to-late apoptotic cells, and $\mathrm{FITC}^{-} / \mathrm{PI}^{+}$represents necrotic cells. Xestospongin C $(100 \mathrm{nM})$ had no effect on cell apoptosis, exposure to $1 \mathrm{MAC}$ isoflurane for $12 \mathrm{~h}$ induced cell apoptosis, and inhibition of the activity of $\mathrm{IP}_{3} \mathrm{R}$ could partly reduce isoflurane-induced cell apoptosis. 


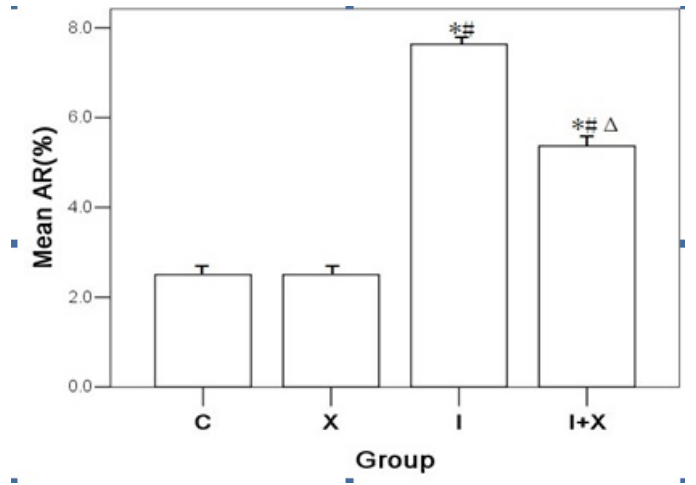

Figure 2. Comparisons of apoptosis rate of the four treatment groups by the annexin V/PI assay. Data are reported as means $\pm \mathrm{SD}$. Compared to group $\mathrm{C},{ }^{*} \mathrm{P}<0.05$; compared to group $\mathrm{X},{ }^{\sharp} \mathrm{P}<0.05$; compared to group $\mathrm{I},{ }^{\Delta} \mathrm{P}<0.05$.

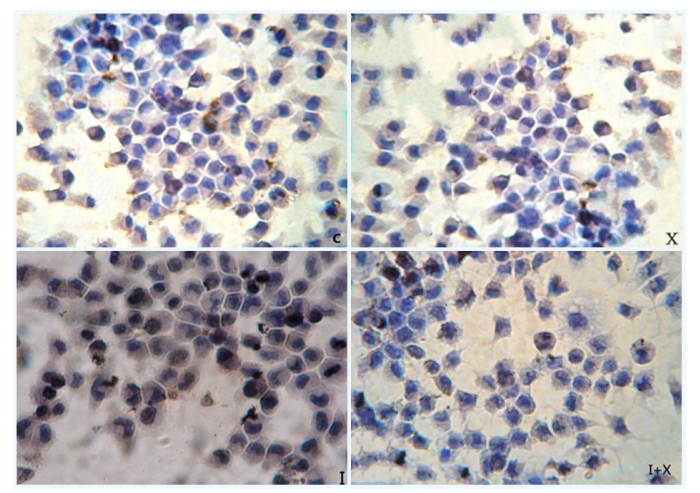

Figure 3. Apoptosis index (AI) determined by the TUNEL Assay (400X). Apoptotic cells are brown, and are considered as TUNEL-positive cells. The percentage of TUNEL-positive cells on each slice in different planes was used to determine cell apoptosis. Xestospongin $\mathrm{C}$ at a concentration of $100 \mathrm{nM}$ had no effect on cell apoptosis, exposure to $1 \mathrm{MAC}$ isoflurane for $12 \mathrm{~h}$ induced cell apoptosis, and inhibition of the activity of $\mathrm{IP}_{3} \mathrm{R}$ could partly reduce isoflurane-induced cell apoptosis.

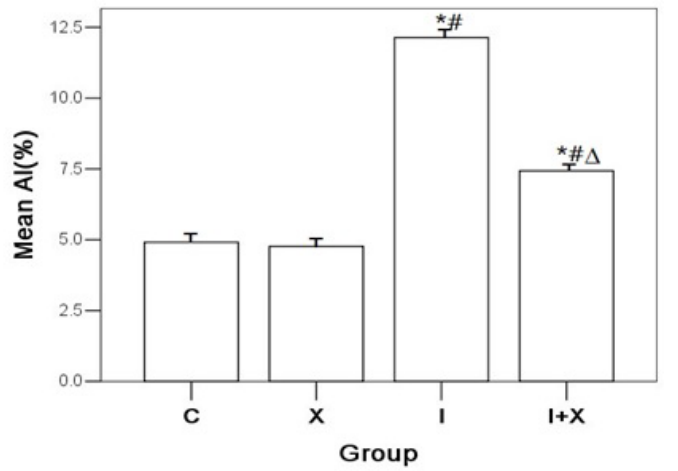

Figure 4. Comparison of apoptosis index (AI) of the four treatment groups by TUNEL assay. Data are reported as means $\pm \mathrm{SD}$. Compared with group $\mathrm{C},{ }^{*} \mathrm{P}<0.05$; compared to group $\mathrm{X},{ }^{\sharp} \mathrm{P}<0.05$; compared to group $\mathrm{I},{ }^{\Delta} \mathrm{P}<0.05$. 


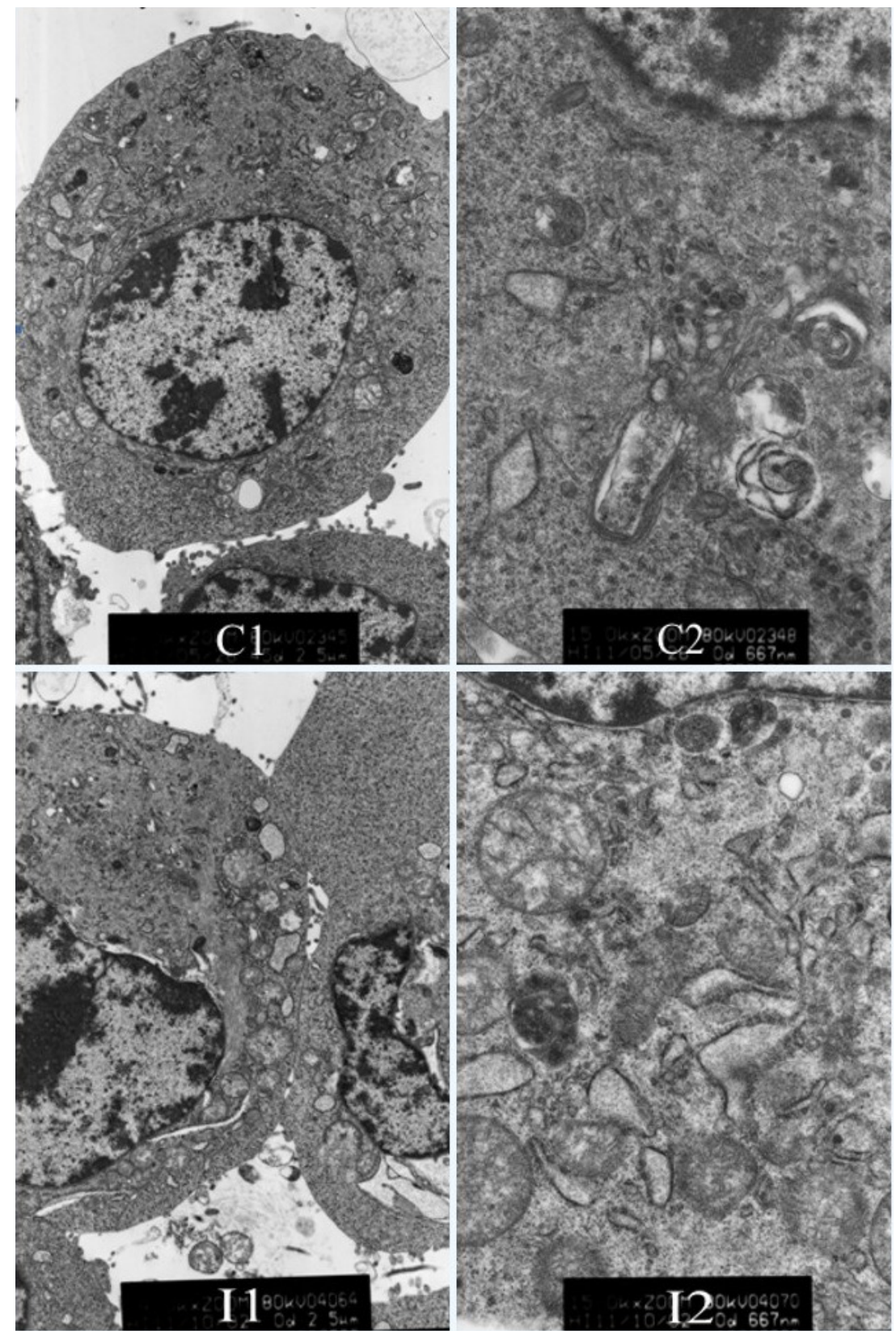

Figure 5. Ultrastructure of $\mathrm{PC} 12$ cells determined by transmission electron microscopy (TEM). $\mathrm{C}_{1}$ : Group C (4000X). $\mathrm{C}_{2}$ : Group C $(15,000 \mathrm{X})$. I $\mathrm{I}_{1}$ : Group I $(4000 \mathrm{X})$. $\mathrm{I}_{2}$ : Group I $(15,000 \mathrm{X})$. The cells in group C had a smooth nuclear membrane, and slight expansion and degranulation of the ER. In group I, the nuclear shape changed, the nuclear chromatin boundary shifted, the perinuclear gap mildly broadened, the density of ribosomes increased, the structure of organelles was incomplete, the mitochondria and ER showed moderate to high swelling, the crest of mitochondria were disordered, membrane structure was damaged, and microtubule microfilament content increased. These ultrastructural changes indicated that exposure to $1 \mathrm{MAC}$ isoflurane for $12 \mathrm{~h}$ induced cell injury. 


\section{Isoflurane caused marked elevation in $\left[\mathrm{Ca}^{2+}\right]_{i}$}

We observed that compared to group $\mathrm{C},\left[\mathrm{Ca}^{2+}\right]_{\mathrm{i}}$ increased in groups $\mathrm{I}$ and $\mathrm{I}+\mathrm{X}(\mathrm{P}<$ $0.05)$, but there was no significant difference in group $\mathrm{X}(\mathrm{P}>0.05)$. Compared to group $\mathrm{X}$, $\left[\mathrm{Ca}^{2+}\right]_{\mathrm{i}}$ increased in groups I and I+X $(\mathrm{P}<0.05)$, and compared to group I, $\left[\mathrm{Ca}^{2+}\right]_{\mathrm{i}}$ decreased in group I+X $(\mathrm{P}<0.05)$ (Table 1, Figures 6 and 7). These results suggest that $100 \mathrm{nM}$ xestospongin $\mathrm{C}$ had no effect on $\left[\mathrm{Ca}^{2+}\right]_{\mathrm{i}}$ and that exposure to $1 \mathrm{MAC}$ isoflurane for $12 \mathrm{~h}$ elevated intracellular calcium, which might have been associated with $\mathrm{IP}_{3} \mathrm{R}$ activity. Inhibition of $\mathrm{IP}_{3} \mathrm{R}$ activity reduced the increase in $\left[\mathrm{Ca}^{2+}\right]_{\mathrm{i}}$ induced by isoflurane.
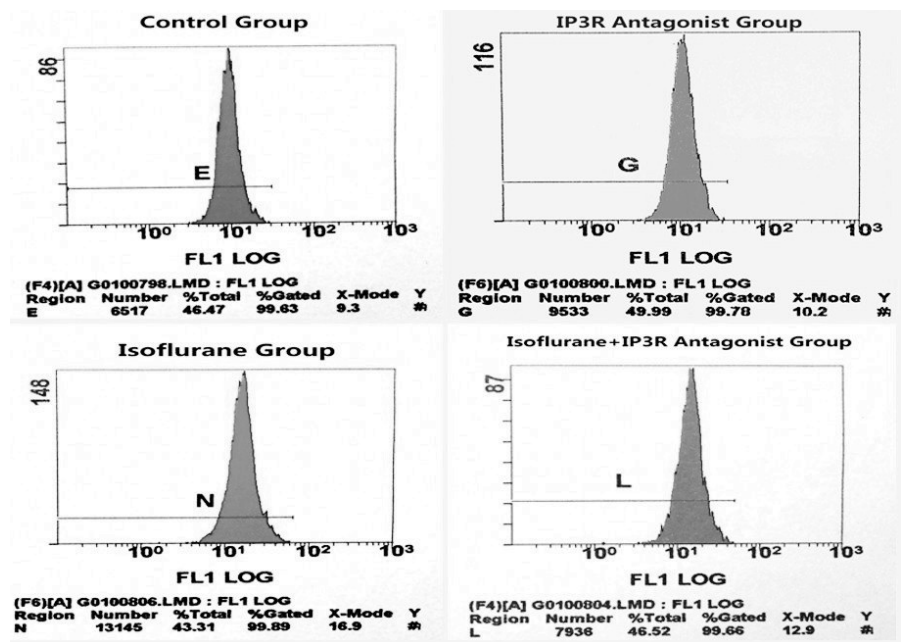

Figure 6. Calcium concentration in cytoplasm $\left(\left[\mathrm{Ca}^{2+}\right]_{\mathrm{i}}\right)$ measured by flow cytometry $(\mathrm{FCM})$. The positive rate of $\left[\mathrm{Ca}^{2+}\right]_{\mathrm{i}}$ loading with Fluo-3/AM was above $99 \%$. X axis is the average value of calcium fluorescence intensity, and $\mathrm{Y}$ axis is cell volume. Xestospongin $\mathrm{C}(100 \mathrm{nM})$ had no effect on $\left[\mathrm{Ca}^{2+}\right]_{\mathrm{i}}$, exposure to $1 \mathrm{MAC}$ isoflurane for $12 \mathrm{~h}$ induced a marked elevation of $\left[\mathrm{Ca}^{2+}\right]_{i}$, which may be associated with the activity of $I_{3} R$. Inhibition of the activity of $\mathrm{IP}_{3} \mathrm{R}$ partly reduced isoflurane-induced increases in calcium.

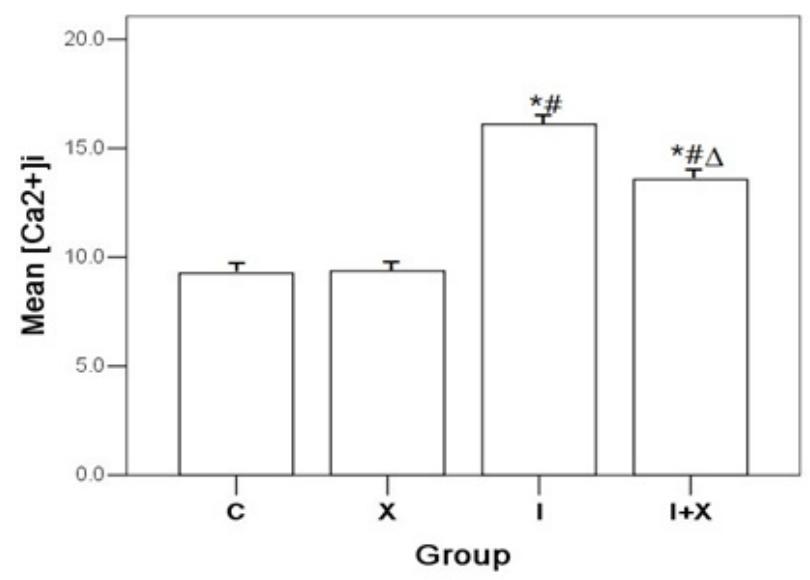

Figure 7. Comparisons of calcium concentrations in cytoplasm $\left(\left[\mathrm{Ca}^{2+}\right]_{\mathrm{i}}\right)$ of the four treatment groups. Data are reported as means $\pm \mathrm{SD}$. Compared to group $\mathrm{C},{ }^{*} \mathrm{P}<0.05$; compared to group $\mathrm{X},{ }^{*} \mathrm{P}<0.05$; compared to group $\mathrm{I},{ }^{\Delta} \mathrm{P}<0.05$. 


\section{Effects of isoflurane on IP $R$ mRNA expression}

$\mathrm{IP}_{3} \mathrm{R}$ mRNA expression was lower in group $\mathrm{X}$, higher in group $\mathrm{I}(\mathrm{P}<0.05)$, and unchanged in group $\mathrm{I}+\mathrm{X}(\mathrm{P}>0.05)$, as compared to group $\mathrm{C}$. Compared to group $\mathrm{X}, \mathrm{IP}_{3} \mathrm{R}$ mRNA expression was higher in groups I and $\mathrm{I}+\mathrm{X}(\mathrm{P}<0.05)$, and compared to group I, $\mathrm{IP}_{3} \mathrm{R}$ mRNA expression was lower in group I+X $(\mathrm{P}<0.05)$ (Table 1, Figures 8 and 9). The results demonstrated that $100 \mathrm{nM}$ xestospongin $\mathrm{C}$ downregulated $\mathrm{IP}_{3} \mathrm{R}$ mRNA expression. Isoflurane exposure at $1 \mathrm{MAC}$ for $12 \mathrm{~h}$ increased $\mathrm{IP}_{3} \mathrm{R}$ gene expression, and inhibition of $\mathrm{IP}_{3} \mathrm{R}$ activity did not completely block isoflurane-induced upregulation of $\mathrm{IP}_{3} \mathrm{R}$ mRNA expression.

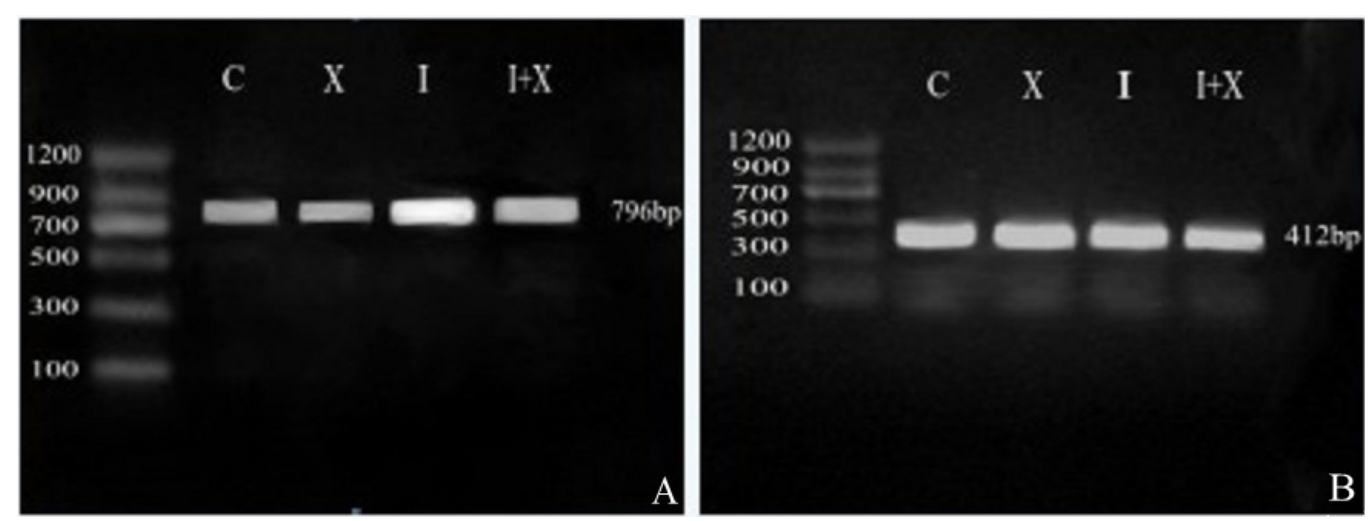

Figure 8. IP $\mathrm{I}_{3} \mathrm{mRNA}$ expression by RT-PCR. A. Representative gel images of $\mathrm{IP}_{3} \mathrm{R}$ results from the four treatment groups. B. Representative gel images of GAPDH (positive control) results from the four treatment groups. The gray value ratio of the sample and GAPDH strip reflected the mRNA expression. Xestospongin C (100 nM) downregulated $\mathrm{IP}_{3} \mathrm{R}$ mRNA expression. Exposure to $1 \mathrm{MAC}$ isoflurane for $12 \mathrm{~h}$ increased $\mathrm{IP}_{3} \mathrm{R}$ gene expression, and inhibition of the activity of $\mathrm{IP}_{3} \mathrm{R}$ completely reduced the isoflurane-induced upregulation of $\mathrm{IP}_{3} \mathrm{R}$ mRNA expression.

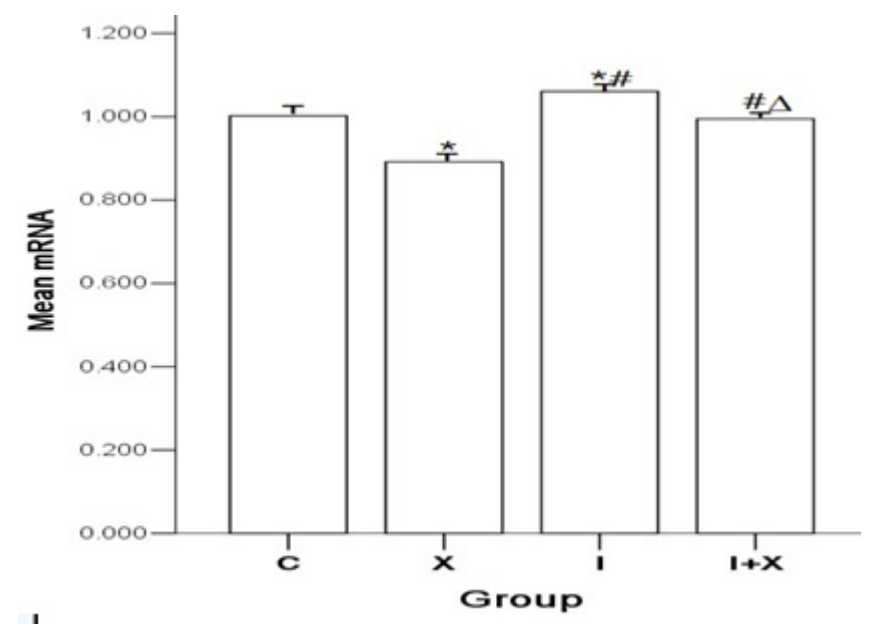

Figure 9. Comparisons of $\mathrm{IP}_{3} \mathrm{R}$ mRNA expression by RT-PCR. Densitometric quantifications of relative band intensities from RT-PCR for each indicated mRNA. Data are reported as means $\pm \mathrm{SD}$. Compared to group $\mathrm{C}, * \mathrm{P}<$ 0.05 ; compared to group $\mathrm{X},{ }^{\sharp} \mathrm{P}<0.05$; compared to group $\mathrm{I},{ }^{\Delta} \mathrm{P}<0.05$. 


\section{DISCUSSION}

In this study, isoflurane at $1 \mathrm{MAC}$ for $12 \mathrm{~h}$ induced cell apoptosis due to the elevation of $\left[\mathrm{Ca}^{2+}\right]_{i}$, and this effect was reversed by the specific $\mathrm{IP}_{3} \mathrm{R}$ antagonist xestospongin $\mathrm{C}$, suggesting a role for $\mathrm{IP}_{3} \mathrm{R}$ in isoflurane-induced cell apoptosis. To our knowledge, this study is the first to demonstrate a direct interaction between isoflurane and $\mathrm{IP}_{3} \mathrm{R}$ on the ER membrane. Strong evidence was provided in support of a mechanism by which isoflurane, and perhaps other inhalational anesthetics, cause cell apoptosis partly via excessive activation of $I_{3} R$. Given that calcium release from the ER via $\mathrm{IP}_{3} \mathrm{R}$ plays an important role in many cellular functions, the results of this study may lead to future work on the pharmacological or side effects of general anesthetics.

Our previous and present studies showed that calcium release from intracellular stores in the ER seems to contribute to the majority of isoflurane-triggered elevation of $\left[\mathrm{Ca}^{2+}\right]_{i}$, which was mostly abolished by the $\mathrm{IP}_{3} \mathrm{R}$ antagonist xestospongin $\mathrm{C}$. Primary rat cortical neurons are vulnerable to isoflurane cytotoxicity but not sevoflurane cytotoxicity. Dysregulation of calcium rather than changes in reactive oxygen species production underlies the cytotoxic effects of anesthetics (Wang et al., 2008). The downstream mechanism by which isoflurane induces apoptosis is relatively unknown. In an earlier study, exposure to $0.6 \%$ isoflurane for $24 \mathrm{~h}$ increased the viability of primary rat cortical neurons, while exposure to $1.2 \%$ isoflurane for 12 or $24 \mathrm{~h}$ and to $2.4 \%$ isoflurane for 8,12 or $24 \mathrm{~h}$ decreased cell viability, which might have been related to changes in $\left[\mathrm{Ca}^{2+}\right]_{\mathrm{i}}$ in the neurons (Wang et al., 2010).

In this study, ultrastructural modifications in cells after exposure to isoflurane, as determined by TEM, showed swelling of the mitochondria and the ER in addition to nuclear changes. The abnormal changes in the structure of the ER can induce calcium flow into the cytoplasm, which can cause the $\left[\mathrm{Ca}^{2+}\right]_{\mathrm{i}}$ to quickly increase and participate in inducing apoptosis. Some studies have proposed that the apoptotic pathway of ER-induced apoptosis ultimately occurs through the mitochondrial pathway, and thus the abnormal changes of the mitochondria may be caused by changes in the ER (Ferrari et al., 2010; Ma et al., 2010).

In addition, in this study, microtubule and microfilament content increased after isoflurane exposure. Microtubules are an important component of the cytoskeleton, and are related to mitosis, intracellular translocation, overall cellular morphology, cell markers, and a variety of other functions. The structural integrity of microtubules is the basis of nutrient transport between the nerve cell body and axons in nerve cells. A large number of clinical-pathological studies have shown that there is a parallel relationship between neuronal density containing neurofibrillary tangles in the joint cortex and the degree of dementia (Rapp et al., 2008, 2010). In this study, we did not find typical apoptotic bodies by TEM, suggesting that apoptosis may occur at an earlier stage.

Apoptosis is a form of programmed cell death that can be triggered by various signals (Elmore, 2007; Giorgi et al., 2008). Broadly speaking, there are three major apoptotic pathways: the death receptor pathway (Ashkenazi and Vishva, 1998), mitochondrial pathway (Jeong and Seol, 2008) and ER pathway (Breckenridge et al., 2003). The apoptosis cascade process includes a group of proteolytic enzymes called caspases, which can be activated by various types of stimulation. Our previously published and current data suggest that the over-activation of $\mathrm{IP}_{3} \mathrm{R}$ contributes to isoflurane-induced calcium elevation and cell apoptosis. Excessive calcium release from the ER via $\mathrm{IP}_{3} \mathrm{R}$ could cause calcium overload in the mitochondria, as well as depletion of ER calcium (Marc and Mark, 2011; Zhivotovsky and Orrenius, 2011). Furthermore, calcium overload in the mitochondria has been shown to cause cytochrome c release (Pinton et al., 2008), which can activate caspase-3 (Hanson et al., 2004). 
Thus, excessive and/or prolonged activation of $\mathrm{IP}_{3} \mathrm{R}$ by isoflurane may result in apoptosis. In support of this hypothesis, our data clearly showed that prolonged isoflurane exposure caused cell apoptosis via direct activation of $\mathrm{IP}_{3} \mathrm{R}$. In addition, the $\mathrm{IP}_{3} \mathrm{R}$ antagonist xestospongin $\mathrm{C}$ could reduce the rate of cell apoptosis. On the basis of this, we hope to develop a therapeutic approach that targets $\mathrm{IP}_{3} \mathrm{R}$, and as such, the antagonist should cross the blood-brain barrier after intraperitoneal injection so that patients undergoing inhalational anesthesia can be protected from the possible deleterious side effects of prolonged exposure.

It has long been known that anesthetics such as halothane activate RyR, the other major calcium release channel complex on the ER (Duke et al., 2010). Like IP ${ }_{3}$, RyR also plays an important role in both normal cell function and various neurodegenerative diseases. Both $\mathrm{IP}_{3} \mathrm{R}$ and RyR contribute to the regulation of intracellular calcium homeostasis and may interact with each other to mediate isoflurane-induced cell apoptosis (Luciani et al., 2009). Thus, studies should investigate the possible interaction between $\mathrm{IP}_{3} \mathrm{R}$ and RyR during exposure to inhalational anesthetics.

It is unclear whether all inhalational anesthetics directly activate $\mathrm{IP}_{3} \mathrm{R}$. Sevoflurane, a relatively new inhalational anesthetic, does not induce similar elevations of $\left[\mathrm{Ca}^{2+}\right]_{\mathrm{i}}$ or neurotoxicity as isoflurane at equipotent concentrations (Wang et al., 2008). Thus, there is the prospect that other inhalational anesthetics may be less neurotoxic. Ultimately, clinical studies are required to support this notion.

There are several limitations to the present study. 1) PC12 cells are rat neurosecretory cells, not neurons. Therefore, the sensitivity to isoflurane exposure may be different, and the concentration and time of isoflurane exposure that induces cell apoptosis may be different. 2) All results are from cultured cell lines. Brambrink et al. (2010) exposed postnatal day 6 rhesus macaque to a surgical plane of isoflurane anesthesia for $5 \mathrm{~h}$, and through biochemical assays revealed widespread neuroapoptosis affecting all divisions of the cerebral cortex. However, they did not determine behavioral changes. Thus, more animal studies are needed, in both rodents and primates, to investigate the effect of isoflurane exposure on animal memory, cognition and behavior.

In summary, our results indicate that exposure to isoflurane may induce excessive calcium release and cell apoptosis via direct activation of $\mathrm{IP}_{3} \mathrm{R}$ on the ER. More importantly, pharmacological inhibition of this receptor mostly prevents isoflurane-induced cell apoptosis. This study provides a mechanism to explain anesthesia-induced cell apoptosis and identifies $\mathrm{IP}_{3} \mathrm{R}$ as a potential therapeutic target for prevention of the effects of prolonged exposure to anesthetics.

\section{Conflicts of interest}

The authors declare no conflict of interest.

\section{ACKNOWLEDGMENTS}

Research supported by the National Natural Science Foundation of China (NSFC) (\#30972832) and the Natural Fund in Hebei Province (\#C2009001187).

\section{REFERENCES}

Ashkenazi A and Vishva M (1998). Dixit Death receptors: signaling and modulation. Science 281: 1305-1308. Bittner EA, Yue Y and Xie ZC (2011). Brief review: Anesthetic neurotoxicity in the elderly, cognitive dysfunction and Alzheimer's disease. Can. J. Anaesth. 58: 216-223. 
Brambrink AM, Evers AS and Avidan MS (2010). Isoflurane-induced neuroapoptosis in the neonatal rhesus macaque brain. Anesthesiology 112: 834-841.

Breckenridge DG, Germain M, Mathai JP, Nguyen M, et al. (2003). Regulation of apoptosis by endoplasmic reticulum pathways. Oncogene 22: 8608-8618.

Campbell LL, Tyson JA, Stackpole EE, Hokenson KE, et al. (2011). Assessment of general anaesthetic cytotoxicity in murine cortical neurones in dissociated culture. Toxicology 283: 1-7.

Chang YC and Chou MY (2001). Cytotoxicity of halothane on human gingival fibroblast cultures in vitro. J. Endod. 27: $82-84$.

Duke AM, Hopkins PM, Calaghan SC, Halsall JP, et al. (2010). Store-operated $\mathrm{Ca}^{2+}$ entry in malignant hyperthermiasusceptible human skeletal muscle. J. Biol. Chem. 285: 25645-25653.

Elmore SS (2007). Apoptosis: a review of programmed cell death. Toxicol. Pathol. 35: 495-516.

Ferrari D, Pinton P, Campanella M, Callegari MG, et al. (2010). Functional and structural alterations in the endoplasmic reticulum and mitochondria during apoptosis triggered by $\mathrm{C}_{2}$-ceramide and CD95/APO-1/FAS receptor stimulation. Biochem. Biophys. Res. Commun. 391: 575-581.

Giorgi C, Romagnoli A, Pinton P and Rizzuto R (2008). Ca2+ signaling, mitochondria and cell death. Curr. Mol. Med. 8: $119-130$.

Hanson CJ, Bootman MD and Roderick HL (2004). Cell signalling: IP ${ }_{3}$ receptors channel calcium into cell death. Current Biology 14: 933-935.

Jeong SY and Seol DW (2008). The role of mitochondria in apoptosis. BMB reports 7: 11-22.

$\mathrm{Kim}$ H, Oh E, Im H, Mun J, et al. (2006). Oxidative damages in the DNA, lipids, and proteins of rats exposed to isofluranes and alcohols. Toxicology 220: 169-178.

Kvolik S, Glavas-Obrovac L, Bares V and Karner I (2005). Effects of inhalation anesthetics halothane, sevoflurane, and isoflurane on human cell lines. Life Sci. 77: 2369-2383.

Luciani DS, Gwiazda KS, Yang TL, Kalynyak TB, et al. (2009). Roles of $\mathrm{IP}_{3} \mathrm{R}$ and $\mathrm{RyR} \mathrm{Ca}^{2+}$ channels in endoplasmic reticulum stress and $\beta$-ell death. Diabetes 58: 422-432.

Ma H, Jones KR, Guo R, Xu P, et al. (2010). Cisplatin compromises myocardial contractile function and mitochondrial ultrastructure: Role of endoplasmic reticulum stress. Clin. Exp. Pharmacol. Physiol. 37: 460-465.

Mallédant Y, Siproudhis L, Tanguy M, Clerc C, et al. (1990). Effects of halothane on human and rat hepatocyte cultures. Anesthesiology 72: 526-534.

Marc G and Mark PM (2011). Neuronal calcium homeostasis and dysregulation. Antioxidants \& Redox Signaling 14: 1261-1273.

Nour BB, Timothy VM and Michael AH (2002). Capacitative $\mathrm{Ca}^{2+}$ entry in vascular endothelial cells is mediated via pathways sensitive to 2 aminoethoxydiphenyl borate and xestospongin C. Br. J. Pharmacol. 135: 119-128.

Oka T, Sato K, Hori M, Ozaki H, et al. (2002). Xestospongin C, a novel blocker of IP ${ }_{3}$ receptor, attenuates the increase in cytosolic calcium level and degranulation that is induced by antigen in RBL-2H3 mast cells. Br. J. Pharmacol. 135: 1959-1966.

Pinton P, Giorgi C, Siviero R, Zecchini E, et al. (2008). Calcium and apoptosis: ER-mitochondria $\mathrm{Ca}^{2+}$ transfer in the control of apoptosis. Oncogene 27: 6407-6418.

Rapp MA, Schnaider-Beeri M, Purohit DP, Perl DP, et al. (2008). Increased neurofibrillary tangles in patients with Alzheimer disease with comorbid depression. Am. J. Geriatr. Psychiatry 16: 168-174.

Rapp MA, Schnaider-Beeri M, Purohit DP, Reichenberg A, et al. (2010). Cortical neuritic plaques and hippocampal neurofibrillary tangles are related to dementia severity in elderly schizophrenia patients. Schizophr. Res. 20: 90-96.

Wang QJ, Li KZ, Yao SL, Li ZH, et al. (2008). Different effects of isoflurane and sevoflurane on cytotoxicity in primary cortical neurons of rats. Chin. Med. J. 121: 341-346.

Wang QJ, Wang XL, Zhao J, Zhao ZJ, et al. (2010). Effects of different concentrations of isoflurane on viability in rat primary cortical neurons. Chin. J. Anesthesiol. 30: 673-675.

Wang S, Peretich K, Zhao Y, Liang G, et al. (2009). Anesthesia-induced neurodegeneration in fetal rat brains. Pediatr. Res. 66: 435-440.

Wei H, Kang B, Wei W, Liang G, et al. (2005). Isoflurane and sevoflurane affect cell survival and BCL-2/BAX ratio differently. Brain Res. 1037: 139-147.

Wei H, Liang G, Yang H, Wang Q, et al. (2008). The common inhalational anesthetic isoflurane induces apoptosis via activation of inositol 1, 4, 5-trisphosphate receptors. Anesthesiology 108: 251-260.

Wei HF and Xie ZC (2009). Anesthesia, calcium homeostasis and Alzheimer's disease. Curr. Alzheimer Res. 6: 30-35.

Wise-Faberowski L, Zhang H, Ing R, Pearlstein RD, et al. (2005). Isoflurane-induced neuronal degeneration: an evaluation in organotypic hippocampal slice cultures. Anesth. Analg. 101: 651-657.

Xie Z, Dong Y, Maeda U, Alfille P, et al. (2006a) The common inhalation anesthetic isoflurane induces apoptosis and 
increases amyloid beta protein levels. Anesthesiology 104: 988-994.

Xie Z, Dong Y, Maeda U, Moir R, et al. (2006b). Isoflurane-induced apoptosis: A potential pathogenic link between delirium and dementia. J. Gerontol. A Biol. Sci. Med. Sci. 61: 1300-1306.

Xie Z, Dong Y, Maeda U, Moir RD, et al. (2007). The inhalation anesthetic isoflurane induces a vicious cycle of apoptosis and amyloid beta-protein accumulation. J. Neurosci. 27: 1247-1254.

Yang H, Liang G, Hawkins BJ, Madesh M, et al. (2008). Inhalational anesthetics induce cell damage by disruption of intracellular calcium homeostasis with different potencies. Anesthesiology 109: 243-250.

Zhao YF, Liang G and Chen QR (2010). Anesthetic-induced neurodegeneration mediated via inositol 1, 4, 5-trisphosphate receptors. J. Pharmacol. Exp. Ther. 333: 14-22.

Zhivotovsky B and Orrenius S (2011). Calcium and cell death mechanisms: A perspective from the cell death community. Cell Calcium 50: 211-221.

Zhu C, Gao J, Karlsson N, Li Q, et al. (2010). Isoflurane anesthesia induced persistent, progressive memory impairment, caused a loss of neural stem cells, and reduced neurogenesis in young, but not adult, rodents. J. Cereb. Blood Flow Metab. 30: 1017-1030.

Zou X, Liu F, Zhang X, Patterson TA, et al. (2011). Inhalation anesthetic-induced neuronal damage in the developing rhesus monkey. Neurotoxicol. Teratol. 33: 592-597. 